\title{
SOCIAL AWARENESS AND CREATIVITY ENHANCEMENT PROGRAM THROUGH E-LEARNING PLATFORM: A CASE OF MAIZBHANDER FOUNDATION'S MEDDHABIKASH PROGRAM, FATIKCHARI, BANGLADESH
}

\author{
Syed Irfanul Hoque \\ Managing Trustee \\ Darul Irfan Research Institute (DIRI) \\ Fatikchari, Bangladesh \\ Nayeb Sajjadah Nasheen \\ Gausia Ahmadia Manzil \\ Maizbhandar Darbar Sharif \\ Fatikchhari, Chattogram, Bangladesh \\ E-mail: tasauf.darulirfan@gmail.com

\section{Muhammad Ali Asgor} \\ Lecturer \\ Department of Islamic Studies \\ Dilowara Jahan Memorial College \\ Bakolia, Chattogram, Bangladesh \\ Associate Member of DIRI \\ E-mail: tasauf.darulirfan@gmail.com \\ Md Ariful Islam \\ Lecturer \\ Omor Goni M.E.S University College \\ Nasirabad, Chattogram, Bangladesh \\ Associate Member of DIRI \\ E-mail: tasauf.darulirfan@gmail.com
}

\begin{abstract}
Due to the pandemic situation, the whole world is in turmoil. The educational activities are being conducted via an e-Platform in Bangladesh. Social awareness and creativity enhancement Programs have also been limited from the wide range of conventional mode to virtual mode. In the meantime, many Social organizations and educational institutions have failed to manage their regular activities due to lack of technological support. Therefore, the purpose of this study is to examine the success of social awareness and creativity enhancement programs through the e-Learning platform. In order to measure the success of the program a quasi-experimental research design has been applied. In order to collect data, a well-structured creativity, and awareness scale has been adapted. A questionnaire has been administered twice with the same sample. Once before the program offered and again after their participation in the program. The test-retest reliability of the scale would also check with a minimum of $\alpha=80$. Therefore, the findings of the research will show how much the effectiveness of those activities increased. This study will assist the social workers, teachers, students and concerned authority in operating creativity enhancement related co-curricular and non-credited program through selfregulated distance learning in a developing country.
\end{abstract}

Keywords: Virtual Mode, e- Platform, Creativity Enhancement Program, Co-curricular, Non-credit Program 


\section{INTRODUCTION}

The novel corona virus was first reported in Wuhan, China at the end of December 2019; gradually it spread all over the world. Countless people are constantly being affected and deceased all over the world. In Bangladesh, the first three corona virus patients were detected on March 8, 2020,according to the Institute of Epidemiology, Disease Control and Research (IEDCR) (Alam et al., 2020). For such a pandemic situation, the socio-cultural condition of the globe is continually being devastated. The social works and creativity related programs also are being interrupted as far and wide. Most of the socio-cultural programs along with educational activities are widely being conducted virtually. If the case does not improve, this break is further prolonged. Like other countries, Bangladesh is also facing challenges in dealing with this situation. Monitoring matters, the Ministry of Education of Bangladesh has decided to shut all educational institutions until the condition improves significantly.

For maintaining social distancing, the other socio-cultural occasions have also been halted across the country. Meanwhile, the education ministry of Bangladesh has ordered to conduct online classes to all educational institutions as an alternative way so that the dropping out of the students can be prevented at any cost on account of long-time closing. To ensure uninterrupted education among the students, the MoE (Ministry of Education) has started telecasting classes regularly for the students of schools and colleges (Alam, 2020).As a developing country though this process is facing problems due to lack of infrastructure of the internet, it'll draw a good result in the education sector. Since, in Bangladesh, there are 46 public, 105 private universities and 1500 colleges affiliated with the National University of Bangladesh, comparing to the students these institutions are not capable of accommodating and enrolling all of them (Alam, 2020). In this case, distant learning or eLearning can eradicate these barriers and limitations.

\section{PROBLEM STATEMENT}

The Maizbhandar Foundation's Medhabikash Project has been conducting 'The social awareness and creativity enhancement Programs' for a long time among the students of school and Madrasah from class VII to IX. For so long, the authority was accustomed to conduct those programs in a conventional way. Now, they have faced challenges to arrange the programs among the students on account of the Pandemic situation. If those programs are discontinued among them, the social awareness and creativity enhancement among the teenager students will be halted.

Therefore, this year the organization has taken initiative to conduct its campaign via an eLearning Platform due to adversities of the new normal condition. Conducting those programs through the e-Learning Platform has posed a challenge for this organization as they have no prior experience in managing such campaigns via the e-Learning Platform. Even then, it has created a wide range of opportunities and potentiality to spread the programs beyond the rural areas to each corner of the country.

The study has tried to specialize in the effectiveness of the program via the e-Learning Platform. In order to measure the success rate in such a case, a quasi-experimental research design has been used. On account of collecting data, a well-structured creativity, and awareness scale has also been applied. Using the identical sample the questionnaire has been administered twice. Once before the program offered and again after their participation in the program ended. The test-retest reliability of the scale would also check with a minimum of $\alpha=80$. Hopefully, the outcome of the study will be conducive for the students, teachers, Social workers, concerned authority in operating creativity enhancement related co-curricular and non-credited programs through self-regulated webbased or e-Learning platform in developing country like Bangladesh.

The major objectives of the study are:

\section{RESEARCH OBJECTIVES}

- To examine the success of social awareness and creativity enhancement programs through the e-Learning platform

- To study the current situation of the e-Learning Platform in the context of Bangladesh in line with the global situation.

- To find out some strategies and techniques in making the Medhabikash programmore successful in the e-Learning Platform; and 
- To identify the problems and barriers for the students to participate in the program through the e-Learning Platform and make a solution to these.

\section{RESEARCH QUESTIONS}

This study tries to answers the following research questions

- How to examine the success of social awareness and creativity enhancement programs through the e-Learning platform?

- What is the current situation of the e-Learning platform in the context of Bangladesh?

- Which strategies and techniques can be adapted in making the Medhabikash Program more successful in the e-Learning Platform?

- What are the problems and barriers for the students to participate in the Medhabikash Program and how can it be solved?

\section{THE OVERALL STRUCTURE OF THE PAPER}

The overall paper is arranged in the following structure: first of all the 'Literature Review' is included, where we have discussed the theoretical structure of the study. Then, the research methodology is mentioned. Later, we have discussed findings and analysis. Then, we have cited results and discussions. Finally, we have concluded our paper with limitations, recommendations, and a conclusion.

\section{The e-Learning Platform}

\section{LITERATURE REVIEW}

The e-Learning Platform can be defined in many ways. Although the means of the e-Learning Platform are varied procedurally, the whole process depends upon electricity, devices, and therefore the internet. Most of the authors have opined that the social networks that are used to get accessed through the utilization of technology for learning experiences or gaining knowledge are known as ePlatform (Power, 2020) (Farah \& Ahmed, 2014). The e-Learning facilities are also increasing day by day. According to the opinion of Fountain 2001, p 10, technological facilities are growing faster than in previous years. Technological tools like software, hardware, and network capacity are also tremendously being up-to-date which has opened the door to e-learning and digitization all over the world (Uddin \& Uddin, 2020).

\section{The e-Learning in the Context of Bangladesh}

If we take a glance at the historical background of e-Learning in Bangladesh, then we see that it absolutely was first introduced in 1956 by a radio broadcasting program and later the program was expanded in an exceedingly big selection with the establishment of BOU (Bangladesh Open University) in 1992 (Farah \& Ahmed, 2014). Although the concept of e-Learning isn't new, it's implementation has not significantly started in the country. The infrastructure of internet service isn't well structured in rural areas compared to urban areas. The people of rural areas mostly rely upon the frequency of telecom companies. Statistics show that rural people mostly use cell phones to make a call other than using internet services. A survey conducted in 2011 found that rural people are lagging behind compared to the urban people in using the internet (BBS Bangladesh Bureau of Statistics, 2017). However, the current situation has opened a new era of e-Learning for every kind of individuals irrespective of rural and urban people. Since the educational institutions will remain closed almost all around the year until the situation improves, the e-Learning platform is that the only reliable sector in this field.

\section{Overview of Social Awareness and e-Learning Platform}

At present, we are able to see a revolutionary change worldwide because of the development of technology. Electronic technologies have transformed the nature of social work practice. According to Reamer (2013), the nature of social works has transformed into a digital way by the invention of technology. Now those social works are being delivered through online and other electronic technology (Reamer, 2013). He also mentioned in his article some means of delivering social works as a whole such as online counselling, telephone counselling, video counselling, cyber therapy (avatar therapy), self-guided Web-based interventions, electronic social networks, e-mail, and text 
messages (Reamer, 2013). In this age, social workers remain busy giving services to their clients via phone calls, video calls, messaging, and online chatting. Prior to this age, these works were very difficult to deliver to the doorsteps of their clients.

\section{Creativity and e-Learning Platform}

We know that creativity can be a vital factor for a man. If creative thinking skills cannot be developed anyhow, the skilled manpower won't be generated. According to Webster's Dictionary creativity can be defined as having the ability to create (Heilman, 2014). The root word of creativity is 'create' which denotes to bring into being or to produce (Heilman, 2014). Some other definition of creativity is also in vogue what can be defined as marked by originality (Heilman, 2014). Some also opine that the word 'creativity' springs from the Latin word creo which refers to create, to make (Ritter \& Mostert, 2017). Creative thinking is considered as one of the key competencies for the $21^{\text {st }}$ Century. Kaufman and Beghet to have categorized creativity into four divisions as they are (1) Big-C creativity, (2) Pro-C creativity (3) Little-C creativity, and (4) Mini-C creativity (Márquez et al., 2016). Big-C creativity is named 'high' creativity as this type of creativity can be innovated by the elite few who transform their discipline into inventions, Einstein's theory of relativity and Darwin's theory of evolution are included in this sect (Márquez et al., 2016; Hasan \& Islam, 2020). The Pro-C creativity can be developed in a person for a long period, usually; it takes at least ten years. 'Acting with flexibility, intelligence, and novelty in the everyday' are called Little-c creativity. This type of creativity may be developed over a protracted period. An individual who contains such quality can resolve complex problems at work. Mini-C Creativity is often defined as the 'novel and personally meaningful interpretation of experiences, actions, and events'. This sort of creativity is nurtured by teachers and parents (Márquez et al., 2016).

\section{Possibility and Challenges for Social Awareness and Creativity Enhancement Programs Through e-Learning Platform}

The possibilities of e-Learning in creating social awareness and creativity enhancement can bring multiple benefits. According to Graham \& Misanchuk (2004) online media i.e. e-Learning media can draw enormous benefits for the students and teachers in supporting teachings and learning's (Alam, 2020). Not only does e-learning accelerate the facility of teaching and learning, but it also contributes to the overall development and GDP growth of the country. According to the analysis of Kahouli, 2012 ICT (Information and Communication Technology) i; e e-platform can constitute the source of job creation, economic and technological catching up, reduce the transaction costs, distances, increase the productivity of the country and many more (Okon, 2018). If social awareness and creativity enhancement programs are delivered via the e-Platform, it can confer more benefits and advantages for the students than the traditional mode. Some notable benefits are mentioned below:

- According to You \& Kang, a student who favours self-regulated learning, it may be helpful for him (Alam, 2020). In this case, social awareness and creativity enhancement programs can be more conducive than the conventional mode.

- The students can be connected online under any circumstances with none additional preparation disregarding their time and place (Alam, 2020). Boundary and limitation is a barrier to reach each of the students with specific topics. In that case, there is an opportunity to deliver it on an oversized scale through the e-Learning Platform.

- The e-Learning Platform may be a priority basis if some major factors will have available in the country for making successful any reasonable campaign. Among them, a large number of mobile subscribers, internet users, and a well-structured network system may be the most consideration.

According to Association of Mobile Telecom Operators of Bangladesh (2020), the total subscribers of the cell phone are 166.028Million. Where Telenor's Grameen phone Ltd. (GP) is at the top as they have 77.011million subscribers. Robi Axiata Limited (Robi) is in the second place with 49.784 million subscribers. Banglalink Digital Communications Ltd is in the third place with 34.578 million subscribers. Bangladesh's state-owned mobile company Teletalk Bangladesh Ltd. (Teletalk) is in the $4^{\text {th }}$ place with 4.655 million subscribers. The above mentioned data have been 
updated at the end of August 2020 (Association of Mobile Telecom Operators of Bangladesh, 2020).

According to the Bangladesh Telecommunication Regulatory Commission, mobile internet users are rapidly increasing which stands at 108.188 million at the ends of August 2020 (Association of Mobile Telecom Operators of Bangladesh, 2020).Analysing the above data it's been clarified that Bangladesh has a great possibility to be digitalized rapidly in spite of a developing country. As uncertainty is everywhere regarding reopening educational institutions, digitalization can help the students to stay them turned into their curricular activities as well as co-curricular activities.

The challenges and barriers to spread e-Learning concepts in creating social awareness and creativity enhancement are many. Among them, literacy and digital skills are the biggest perceived barrier to adopt mobile internet adoption (GSMA, GSMA Intelligence, UK aid, 2019). In the context of Bangladesh literacy and digital skill don't seem to be such a lot of hindrance, but it's becoming less of a barrier significantly in many countries like Bangladesh. The subsequent data show that lots of barriers are existing in our country regarding digitalization but day by day the barrier is lessening in spite of lack of literacy and digital skills(GSMA, GSMA Intelligence, UK aid, 2019). In 2019, the barrier regarding the use of mobile internet in Bangladesh is a smaller amount than in the year 2018. In this case, Bangladesh is in a better position than other countries. In 2018, the barrier to mobile internet use of our neighbouring country India was 63\% and in 2019 was $59 \%$. And in Pakistan it was $78 \%$ and $79 \%$ respectively. In neighbouring Myanmar, it was $69 \%$ and $74 \%$ respectively (GSMA, GSMA Intelligence, UK aid, 2019).

According to the above information, the barrier of mobile internet use is being lessened in Bangladesh day by day than some other south-east countries like India, Pakistan, Myanmar, and Indonesia. In 2019 the barrier to mobile internet use in Bangladesh was 48\%. Apart from literacy and digital skills, there are many other obstacles to provide social awareness and creativity enhancement programs among the students through e-Learning means which are unavailability of the internet facility in the rural areas, the weak signal of the internet, lack of experience handling smartphone or computer, time management to attend the live classes and sometimes it's uphill in eLearning platform to interact the students(Alam, 2020;).

\section{A Case study of Maizbhandari Foundation's Medhabikash Program}

Anjuman-e-Muttabiyene Gause Maizbhandari (Shah Emdadia) was established by Sajjadanshin-eGauthal-Azam Hazrat Maulana Shah Sufi Syed Delowar Hossain Maizbhandari ® in 1949 A.D (Maizbhandari, 2006). Later, the spiritual heir of his Godi (Chair) Hazrat Maulana Shah Sufi Syed Emdadul Hoque Maizbhandari (M.J.A) founded Maizbhandari Foundation. The Medhabikash Program of the Maizbhandari Foundation is conducted once a year among the students of Schools and Madrasah of rural areas. Medhabikash, an education institution program is run by the Maizbhandari Foundation to develop the intellect and skill of the students in order that an ethical character and humanitarian quality may be developed at tender age among them.

The Medhabikash Program of the Maizbhandari Foundation is split into two types (1) social awareness related programs namely: environmental protection activities, creating awareness about harmful aspects of the intake of chemical food, creating awareness about harmful aspects of the abuse of technology, cleaning, and sanitation program, creating awareness about the nutritional value of food and (2) creativity enhancement related programs that includequiz and creative questions-answers competition, environmental group study cycle, synonym/antonym of Bangla and English, an Ethics card questions-answers competition. This two types of activities can be termed as co-curricular activities. The main purpose of education is the overall development of the students which is comprised of curricular and co-curricular activities.

The Maizbhandari Foundation's Medhabikash Program is patronized by Hazrat Maulana Shah Sufi Syed Emdadul Hoque Maizbhandari (M.J.A) and directed by Nayeb Sajjadanshin Hazrat Maulana Shah Sufi Syed Irfanul Hoque Maizbhandari (M.J.A). The members of the Maizbhandari Foundation collaborating with the teachers of the schools and Madrasahs conduct the program among the students. The all programs of the previous years were held in the school and Madrasah premises or classrooms. It's been observed that an oversized number of students participated spontaneously in those programs and the participants have been beneficiated innumerable the source 
said. The current pandemic situation has raised awful circumstances everywhere and therefore the normal activities of the people are being disrupted. In this case, having a health risk for the students the government doesn't want to reopen the educational institutions. Therefore, the Medhabikash Program has faced problems and is about to stop.

\section{METHODOLOGY}

The study was conducted using a quasi-experimental research design. The sample size was 50 (fifty). With a view to collecting data, a well-structured creativity and awareness scale had been applied. A questionnaire had been developed consisting of 22 (twenty-two) items and making a google form, a link was provided to each student through their WhatsApp number and a time frame was fixed to answer the questions. The participants weren't habituated enough before the test offered with the e-Learning Platform. In this case, they were in an exceedingly hurry to answer resulting they have mistakenly answered very few questions. So, it's been a failure to draw the expected results. The first test was held on October 9, 2020. The second test was held in December 2020. The first test result has been analysed with SPSS and later a paired sample test analysis has been given in 'Results' section of the paper which shows that what quantity has improved their scores significantly with the e-Learning Platform. The table-1shows the number and gender of the participants:

Table 1. The below table shows the gender and number of participants in the Medhabikash Program

\begin{tabular}{|l|l|l|l|l|l|}
\hline \multicolumn{5}{|c|}{ Genders of the participants } & \\
\hline \multirow{3}{*}{ Valid } & Frequency & Percent & $\begin{array}{l}\text { Valid } \\
\text { Percent }\end{array}$ & Cumulative Percent \\
\cline { 2 - 6 } & Male & 17 & 34.0 & 34.0 & 34.0 \\
\cline { 2 - 6 } & Female & 33 & 66.0 & 66.0 & 100.0 \\
\cline { 2 - 6 } & Total & 50 & 100.0 & 100.0 & \\
\hline
\end{tabular}

\section{RESULTS}

The data have been analysed using Statistical Package for the Social Science (SPSS version 25.0). Before using any test or scale, we must check its reliability where test-retest reliability has been checked on the basis of Cronbach alpha of a scale $\alpha=.80$. The most commonly used indicator for internal consistency is Cronbach's alpha coefficient and also the acceptable value of Cronbach's alpha coefficient should be greater than $\alpha=70$. For expected test-retest results, the sample must be reliable, otherwise, it won't be acceptable. The sample items should be more than ten, otherwise, quite low Cronbach's alpha values will result in (e.g $\alpha=.50)$ (Pallant, 2011). Reliability refers to the consistency of a measure. A test or scale is considered reliable if we get an identical result repeatedly. Reliability statistics are given below:

Table 2. The below table shows the valid and excluded participants

\begin{tabular}{|l|c|c|c|}
\hline \multicolumn{4}{|c|}{ Case Processing Summary } \\
\hline \multirow{3}{*}{ Cases } & \multirow{3}{*}{ Valid $^{4}$} & $\mathrm{~N}$ & $\%$ \\
\cline { 2 - 4 } & Excluded $^{\mathrm{a}}$ & 0 & 100.0 \\
\cline { 2 - 4 } & Total & 50 & 0 \\
\cline { 2 - 4 } & & 0 & 100.0 \\
\hline
\end{tabular}

Table 3. The below table shows the reliability statistics of the first test and post test scores

\begin{tabular}{|c|c|c|}
\hline \multicolumn{3}{|c|}{ Reliability statistics } \\
\hline Cronbach's Alpha & $\begin{array}{l}\text { Cronbach's Alpha Based on } \\
\text { Standardized items }\end{array}$ & No of Items \\
\hline .999 & .999 & 2 \\
\hline
\end{tabular}


In Table 3 of the two tables it is shown that Cronbach's Alpha coefficient is greater than $\alpha=.70$ which has stood above $\alpha=.80$. Here, Cronbach's Alpha value is .999 which indicates a high quality reliability of the test.

The findings of the study show that the Maizbhandari Foundation's Medhabikash Program is what proportion has improved through the e-Learning platform. The study has discovered a significant result and effectiveness of the e-Learning Platform among the two versions of the programs. The previous version was the conventional mode and also the latest version is the eLearning platform. The newly adopted version of e-Learning has created endless possibilities. The first test and post-test scores of the participants were assessed employing a T-test Paired sample. The results of the t-test paired sample are attached in Table-4:

Table 4. The below indicates the significant value of Paired samples Test in the heading 'Sig (2tailed)' of the table

\begin{tabular}{|c|c|c|c|c|c|c|c|c|c|}
\hline \multicolumn{10}{|c|}{$\begin{array}{l}\text { Paired Samples Test } \\
\text { Paired Differences }\end{array}$} \\
\hline \multirow{3}{*}{$\begin{array}{c}\text { Pair } \\
1\end{array}$} & \multirow{3}{*}{$\begin{array}{l}\text { The Scores } \\
\text { that have } \\
\text { earned in the } \\
\text { re-test- } \\
\text { The Scores } \\
\text { that have } \\
\text { earned in the } \\
\text { first test }\end{array}$} & & & & \multicolumn{5}{|c|}{$\begin{array}{l}95 \% \text { confidence interval of the } \\
\text { difference }\end{array}$} \\
\hline & & Mean & $\begin{array}{c}\text { Std. } \\
\text { Deviatio } \\
n\end{array}$ & $\begin{array}{l}\text { Std. } \\
\text { Error } \\
\text { Mean }\end{array}$ & lower & Upper & $\mathrm{t}$ & $\mathrm{df}$ & $\begin{array}{l}\mathrm{Sig} \\
(2- \\
\text { tail } \\
\text { ed })\end{array}$ \\
\hline & & -1.82000 & .74751 & .10571 & -2.03244 & -1.60756 & -17.216 & $\begin{array}{l}4 \\
9\end{array}$ & $\begin{array}{c}.00 \\
0\end{array}$ \\
\hline
\end{tabular}

If we look at a glance at the above-Paired Sample Statistics (See Table-4), we discover that there's an instructional effect in the post-test result of the participants. Although the null hypothesis of the first test was that the e-Learning platform is not effective, this sort of hypothesis has been rejected because the post-test score of the participants has improved significantly. If the post-test scores wouldn't be improved the null hypothesis would be overcome in this case. Now we are able to say that the alternative hypothesis has won and created a significant outcome. The mean value of the first test score was 54.38 and the mean value of the post-test score is 56.2000.The mean difference value is -1.82000 (See Table 4). Is the mean difference value statistically significant or not? The answer should be significant as the p-value of the statistics is 0.00 (See Table-4) which is smaller than 0.05. If the p-value is smaller than 0.05 , then the result would be significant. Therefore, we are able to say that the e-Learning platform has proved as significant means to deliver social awareness and creativity enhancement programs.

\section{DISCUSSIONS}

Maizbhandari Foundation's Medhabikash Program has commenced a new horizon in the field of eLearning platform amid the adversities-situation of covid-19. The e-Learning platform has helped the authority tremendously to reach the program in unlimited areas beyond the boundaries of the rural areas. The authority had to spend a lot of exertion and money to implement the program in the previous years, but the e-Learning facilities have eased and relaxed them as well as reduced the cost of the program.

We all know that the e-Learning platform can't be the fully substitute means of the conventional mode in any case. Even then, the facilities of it can't be avoided anyhow. We would say, the e-Learning platform should be kept on a priority basis for the social organizations in order that their services would reach to the doorstep of every people beyond limited areas. Maizbhandari Foundation authority may consider the e-Learning platform for the following years as an alternative way though the adversities condition of coronavirus would escape. Experience has shown that the most obstacles for voluntary organizations is funding. In this case, the funding won't be matter 
because the e-Learning facilities can help them to cut back the cost of the services. As a result, they are going to be able to deliver their services effortlessly for an extended time span.

Maizbhandari Foundation authority has succeeded to rearrange the Medhabikash program overcoming all obstacles through e-Learning platform and has been able to attract the attention of the students, parents, guardians as well as teachers of the educational institutions because the authority has been able to make understand them the ease of use of the e-Learning platform. Apart from this, the authority has a group of devoted and dedicated volunteers who are trained up with the facilities of the e-Learning platform. Above all, the authority has drawn a significant outcome in the field of e-Learning version.

\section{RECOMMENDATIONS}

To improve the new context of education, some recommendations are made below:

- At first, the infrastructure of the internet for ease of use should be improved so that students can access the web easily in the e-Learning platform at a low cost.

- Steps may also be taken to encourage the students and their guardians to use the internet for any purpose especially in the context of eLearning.

- For a seamless e-Learning environment the authority of the program should design, develop, and evaluate the well thought out plan.

- For a fast response and spontaneous participation, the authority should provide just in case of need e-devices and internet data to the participants.

- In particular, the people of the villages should be given priority to get the benefit of good network. Because there are more people living in villages than in cities. About $62.8 \%$ people live in 86000 villages of Bangladesh (Saha, 2020).

- Bangladesh has a population of 3310 people per square mile, three times more than neighbouring India and 36 times more than the United States (Chowdhury \& Hossain, 2018). So, adequate network towers should be set up so that telecommunication and internet services are not disrupted due to congestion.

\section{LIMITATIONS}

The study has some limitations. The study is based on the primary data collected from the students who participated in the e-Learning Platform under the Maizbhandari Foundation's Medhabikash Program. Since there was limited study in this field, so not enough resources are found relevant to the context. In spite of limitations, the study has tried to point out an effective outcome of eLearning.

\section{CONCLUSION}

Maizbhandari Foundation's Medhabikash Program is one of the platforms for building a developed and moral nation. The Medhabikash Programs in the past years have demanded praise among the teachers, students, and guardians. The results of the past years have inspired the authority innumerable to rearrange the program this year amid the adverse situation of Covid-19. Facing a large of challenges the authority has eventually succeeded in arranging the program in the eLearning Platform. If the government and also the mobile companies take proper steps to spread their network frequency and install the frequency tower, the positive result for the e-Learning platform will be going to be accelerated. The population of Bangladesh won't be a burden if the right steps are taken to convert them into productive manpower by training up with technological learning. Then, the massive population will bring happiness, prosperity and development in the field of technology for the country.

\section{REFERENCES}

Alam, M. A. (2020). Challenges and Possibilities of Online Education during Covid-19. 19(April), 1-37. https://doi.org/10.20944/preprints202006.0013.v1

Alam, M. S., Ali, M. J., Bhuiyan, A. B., Solaiman, M., \& Rahman, M. A. (2020). THE IMPACT OF COVID -19 PANDEMIC ON THE ECONOMIC GROWTH IN BANGLADESH: A CONCEPTUAL REVIEW. American Economic \& Social Review, 6(2), 1-12. https://doi.org/10.46281/aesr.v6i2.844 
Association of Mobile Telecom Operators of Bangladesh. (2020). Mobile Phone Subscribers in Bangladesh. August 2020. Retrieved from https://www.amtob.org.bd/home/industrystatics

BBS Bangladesh Bureau of Statistics. (2017). Statistical Pocket Book Bangladesh. In Central Bureau of Statistics. https://doi.org/10.2833/77358

Chowdhury, M. N. M., \& Hossain, M. M. (2018). Population Growth and Economic Development in Bangladesh: Revisited Malthus. American Economic \& Social Review, 5(2), 1-7. https://doi.org/10.46281/aesr.v5i2.326

Farah, S., \& Ahmed, M. S. (2014). Potentials of e-learning in Bangladesh: An Analysis. 13(1). Retrieved from http://ocw.mit.edu/OcwWeb/

GSMA, GSMA Intelligence, UK aid. (2019). The State of Mobile Internet Connectivity 2019. GSMA Reports. Retrieved from https://www.gsma.com/mobilefordevelopment/wpcontent/uploads/2019/07/GSMA-State-of-Mobile-Internet-Connectivity-Report-2019.pdf

Heilman, K. M. (2014). Creativity and The Brain (1st ed.). Taylor \& Francis.

Hasan, Z., \& Islam, K. M. A. (2020). Academic, Financial and Administrative Issues of Online Teaching During Corona Pandemic: The Scenario of Private Universities in Bangladesh. International Journal of Accounting \& Finance Review, 5(1), 116-122.

Maizbhandari, S. D. H. (2006). Gotontantro. Syed Emdadul Hoque Maizbhandari.

Márquez, B. V., Ontiveros, M. Á. C., \& Pons, M. O. (2016). Chapter 4: Innovation and creativity Electricity. Developing the Cambridge Learner Attributes, 11(128-1), 53-74.

Okon, E. O. (2018). Female Labour Force, ICT and Growth Nexus in Nigeria. American Economic \& Social Review, 2(1), 33-41. https://doi.org/10.46281/aesr.v2i1.152

Pallant, J. (2011). SPSS Survival Manual website. Open University Press.

Power, R. (2020). E-Learning Essentials 2020.

Reamer, F. G. (2013). Social work in a digital age: Ethical and risk management challenges. Social Work (United States), 58(2), 163-172. https://doi.org/10.1093/sw/swt003

Ritter, S. M., \& Mostert, N. (2017). Enhancement of Creative Thinking Skills Using a CognitiveBased Creativity Training. Journal of Cognitive Enhancement, 1(3), 243-253. https://doi.org/10.1007/s41465-016-0002-3

Saha, G. C. (2020). Rural Socio-Economic Development through Tourism in Bangladesh: Ways and Means. American Economic \& Social Review, 6(1), 8-23. https://doi.org/10.46281/aesr.v6i1.507

Uddin, M. G., \& Uddin, M. (2020). E-Government Development \& Digital Economy: Relationship. American Economic \& Social Review, 6(1), 39-54. https://doi.org/10.46281/aesr.v6i1.580

\section{Copyrights}

Copyright for this article is retained by the author(s), with first publication rights granted to the journal. This is an open-access article distributed under the terms and conditions of the Creative Commons Attribution license (http://creativecommons.org/licenses/by/4.0/) 